九州大学学術情報リポジトリ

Kyushu University Institutional Repository

\title{
Changes in the Combustion Characteristics of Living Leaves of Pinus Densiflora by Altitude
}

Lee, Hae-Pyeong

School of Fire \& Disaster Prevention, Kangwon National University

Park, Young-Ju

School of Fire \& Disaster Prevention, Kangwon National University

Lee, Si Young

Professional Graduate School of Disaster Prevention, Kangwon National University

Cha, Joo Yanng

Field Science Center for Northern Biosphere, Hokkaido University

他

https://doi.org/10.5109/18831

出版情報: 九州大学大学院農学研究院紀要. 55 (2)，pp.209-213，2010-10-29. Faculty of Agriculture, Kyushu University

バージョン：

権利関係 : 


\title{
Changes in the Combustion Characteristics of Living Leaves of Pinus Densiflora by Altitude
}

\author{
Hae-Pyeong LEE ${ }^{1}$, Young-Ju PARK ${ }^{1}$, Si Young LEE ${ }^{2 *}$, \\ Joo Young CHA ${ }^{3}$ and Shoji OHGA
}

\author{
Laboratory of Forest Resources Management, Division of Forest Environmental Sciences, \\ Department of Agro-environmental Science, Faculty of Agricultare \\ Kyushu University, Sasaguri, Fukuoka 811-2415, Japan \\ (Received May 20, 2010 and accepted July 9, 2010)
}

\begin{abstract}
Combustion tests were conducted with living leaves of $P$. densiflora to examine the combustion characteristics of this species at different altitudes. An ignition temperature tester, cone calorimeter, and smoke density chamber were used for the tests. Leaf moisture content was measured prior to combustion, yielding a range of between 148 and $177 \%$. The temperature of non-flame ignition was $300 \sim 310^{\circ} \mathrm{C}$ and did not vary with altitude. Flame ignition occurred in the samples taken at $900 \mathrm{~m}$ and $1300 \mathrm{~m}$, but lasted for only 7 and $8 \mathrm{~s}$, respectively. These two samples released similar heat, with the sample from $1300 \mathrm{~m}$ producing slightly more heat. The sample from $1400 \mathrm{~m}$ released more than twice the smoke yielded by the other samples. Maximum smoke density was highest for the higher altitude samples, and the amount of smoke released varied proportionately with altitude. The mean release density of CO increased abruptly at $1100 \mathrm{~m}$ and decreased after that point before an abrupt increase at $1500 \mathrm{~m}$, and that of $\mathrm{CO}_{2}$ showed almost the same pattern as for $\mathrm{CO}$
\end{abstract}

\section{INTRODUCTION}

Along the east coast of South Korea, most large-scale forest fires occur during the months of March and April. This season is marked by warm, dry winds that can accelerate the spread of fires. Other contributors to fires in this season include the presence of dry forest fuel (resulting from dry weather conditions), consistent winds, and accumulated organic matter (Kim, 2005). Major controlling factors are local topography (situation and slope gradient), the type, distribution, and density of fuel, and meteorological factors such as humidity and wind velocity. It is difficult to attribute a single factor as the cause of forest fires. Rather, the causes vary, and, in turn, lead to varying behavioral characteristics of forest fires (Lee, 2006).

To predict forest fire occurrence and mitigate associated dangers, country- and region-specific surveys should be carried out to examine the causes and characteristics of forest fires. In addition, studies must also clarify the combustion characteristics of various types of vegetation according to regional topography, weather, and topographic characteristics (Kim et al., 2006; Chae et al., 2003; Jung et al., 2002). To predict the potential hazard a particular fuel represents, and thus develop appropriate technology and systems for hazard management, data from indoor and outdoor experiments on the effects of vegetation distribution and type are needed (Chun et al., 2001; Lee, 2004). Recent studies in Korea

1 School of Fire \& Disaster Prevention, Kangwon National University, Samcheok, 245-711, Korea

2 Professional Graduate School of Disaster Prevention, Kangwon National University, Samcheok, 245-711, Korea

3 Field Science Center for Northern Biosphere, Hokkaido University, Nayoro, 096-0071, Japan

* Corresponding author (E-mail: lsy925@kangwon.ac.kr) have examined the combustion characteristics of forest fuel with the intention of developing dynamic predictions of fire intensity; however, further work is required (Lee et al., 2005).

In this study, we examined the different fire characteristics of a typical forest fuel collected at different altitudes. Living leaves of Pinus densiflora Sieb. et Zucc. were used as the sample fuel because this species is the most susceptible to combustion in the study area. The moisture content of the leaves was measured before combustion and the characteristics of ignition, fire, and smoke release were measured using an ignition temperature chamber, a cone calorimeter, and a smoke density chamber, respectively.

\section{MATERIALS AND METHODS}

\section{Site selection}

\subsection{Study site and fuel}

Mt. Taebaek $(1567 \mathrm{~m})$ in Gangwon Province was chosen as the study location because its topography and vegetation are typical of the east coast of Korea, where most large-scale forest fires occur. Living leaves of $P$. densiflora were used as the test fuel. This species is highly susceptible to fire and was chosen in order to replicate the conditions of actual forest fires. Seven fuel samples were taken along a hiking trail at intervals of $100 \mathrm{~m}$ between altitudes of $900 \mathrm{~m}$ to $1500 \mathrm{~m}$. The samples were collected in October, after 5 consecutive days of fine weather conditions.

\subsection{Measuring moisture content}

Before combustion characteristic tests were conducted, the moisture content of the sample fuel was measured. Moisture content was measured using formula (1) according to ASTM D2016 (American Society for 
Table 1. Experimental conditions of the smoke density chamber and cone calorimeter

\begin{tabular}{lcc}
\hline Items & Cone calorimeter & Smoke density chamber \\
\hline Size $(\mathrm{mm})$ & $100 \times 100$ & $75 \times 75$ \\
Weight $(\mathrm{g})$ & 50 & 10 \\
Heat flux $\left(\mathrm{kW} / \mathrm{m}^{2}\right)$ & 50 & 25 \\
Test time $(\mathrm{s})$ & the time until there is no & 1,200 \\
Material condition & more weight decrease & Raw \\
\hline
\end{tabular}

Testing and Material) (Kim et al., 2004; Shim et al., 1994). A $200-\mathrm{g}$ sample was dried in a $103^{\circ} \mathrm{C}$ oven for 24 hours, and was then measured until it reached constant mass. The mean value of three measured values was used as the outcome value. Samples were collected in October, after 5 consecutive fine days. MC (moisture content) is the moisture content ratio [\%], W represents the weight of samples before drying [g], and W0 is the weight of dried samples.

$$
M C(\%)=\frac{W-W_{0}}{W_{0}} \times 100(\%)
$$

\subsection{Combustion characteristic tests}

To test the combustion characteristics of living $P$. densiflora leaves with altitude variation, tests on the characteristics of ignition, fire, and smoke release were conducted. To analyze the characteristics of ignition, ignition temperature (IT), time to ignition (TTI) and time to flameout (TTF) were measured. For an analysis of fire characteristics, total heat release (THR) and mean heat release rate (mean HRR) were used, and for the characteristics of smoke release, total smoke release (TSR), maximum smoke density (max. Ds), and smoke temperature (Ts) were measured. The mean release densities of the combustion products $\mathrm{CO}$ and $\mathrm{CO}_{2}$ were also analyzed.

\section{Methods}

\subsection{Analysis of ignition characteristics}

To analyze ignition characteristics, non-flame IT was measured using an IT chamber (model number KRS-RG-9000; Kuramochi Co., Japan; Hong et al., 1992). The time for flash ignition, when fuel was exposed to radiation, was recorded using a cone calorimeter. Flame close time, namely, the time when the fire was extinguished naturally, was measured and after-flame time was analyzed simultaneously. The presence or absence of a flame at flash ignition was recorded, as judged by the naked eye.

\subsection{Analysis of fire characteristics}

To examine fire characteristics, a dual cone calorimeter chamber (ISO 5660-1, 2002) of FTT Co., England was used to analyze the mean HRR. The experiment ended when the sample stopped decreasing in weight, and this value was chosen as the output value. The mean value of three replicates was used as the outcome value. The THR was calculated based on the accumulated value by integrating the heat release rate, represented by a function of time, per its sample's surface area. The mean
HRR was calculated by dividing the THR by the given amount of time. The experimental conditions are presented in Table 1.

\subsection{Analysis of smoke release characteristics}

To analyze the characteristics of smoke release, a smoke density chamber (ASTM E 662, 2003) and cone calorimeter (FTT Co.) were used. TSR and Ts were measured with the cone calorimeter, and smoke density was analyzed using the smoke density chamber. Since TSR measured by the cone calorimeter is the total smoke occurrence per unit area according to ISO 5660-2 (ISO 5660-2, 2002), and as smoke occurs in proportion to area, a standard value related to the area was used.

The total smoke occurrence rate $\left(\mathrm{m}^{2}\right)$ was the value integrated by the time of smoke release $\left(\mathrm{m}^{2} / \mathrm{s}\right)$ in the related section. Ts was measured using a thermocouple when the smoke had passed through a $0.5^{-} \mathrm{mW}$ heliumneon laser in a duct. For the measurement of smoke density, a smoke density chamber was used, applying a vertical test of non-flaming. The mean value of three replicates was used as the outcome value. Experimental conditions are presented in Table 1.

\section{RESULTS AND DISCUSSION}

\section{Moisture content}

The living leaves of $P$. densiflora from the various altitudes contained between $148 \%$ and $177 \%$ moisture (Fig. 1). The curve in Figure 1 shows that the moisture content of the leaves increased with altitude up to $1100 \mathrm{~m}$ after which the moisture content decreased as the altitude increased. The results of the moisture content measurements were as follows. $152.01 \%$ for the

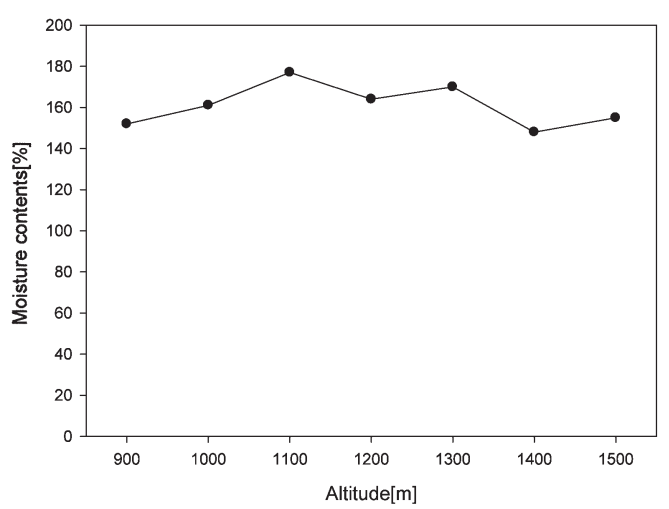

Fig. 1. Moisture content (\%) of living leaves of $P$. densiflora by altitude. 
Table 2. Ignition characteristics of living leaves of $P$. densiflora from different altitudes

\begin{tabular}{|c|c|c|c|c|c|c|c|}
\hline \multirow{2}{*}{ Items } & \multicolumn{7}{|c|}{ Altitudes (m) } \\
\hline & 900 & 1000 & 1,100 & 1,200 & 1,300 & 1,400 & 1,500 \\
\hline Time to ignition (s) & 48 & $\begin{array}{l}\text { not } \\
\text { recorded }\end{array}$ & $\begin{array}{l}\text { not } \\
\text { recorded }\end{array}$ & $\begin{array}{l}\text { not } \\
\text { recorded }\end{array}$ & 63 & $\begin{array}{l}\text { not } \\
\text { recorded }\end{array}$ & $\begin{array}{c}\text { not } \\
\text { recorded }\end{array}$ \\
\hline Time to flameout (s) & 52 & $\begin{array}{l}\text { not } \\
\text { recorded }\end{array}$ & $\begin{array}{l}\text { not } \\
\text { recorded }\end{array}$ & $\begin{array}{l}\text { not } \\
\text { recorded }\end{array}$ & 65 & $\begin{array}{c}\text { not } \\
\text { recorded }\end{array}$ & $\begin{array}{c}\text { not } \\
\text { recorded }\end{array}$ \\
\hline Ignition temperature $\left({ }^{\circ} \mathrm{C}\right)$ & 308 & 308 & 310 & 310 & 308 & 305 & 310 \\
\hline
\end{tabular}

sample for $900 \mathrm{~m}$; $161.20 \%$ for $1000 \mathrm{~m}$; $176.80 \%$ for $1100 \mathrm{~m} ; 164.38 \%$ for $1200 \mathrm{~m} ; 169.62 \%$ for $1300 ; 147.54 \%$ for $1400 \mathrm{~m}$, and $154.83 \%$ for $1500 \mathrm{~m}$.

\section{Ignition characteristics}

Table 2 shows the variation in ignition characteristics for live $P$. densiflora leaves from different altitudes. The ignition temperature shown in Table 2 is the nonflame ignition temperature and is relatively consistent at $305 \sim 310^{\circ} \mathrm{C}$. The times to ignition and flameout were recorded for the $900 \mathrm{~m}$ and $1300 \mathrm{~m}$ samples, but not at the other altitudes because, as with the cone calorimeter, only flame ignition times, not non-flame ignition times, were recorded in this study. Notably, although flame ignition was only initiated at $900 \mathrm{~m}$ and $1300 \mathrm{~m}$, the flames disappeared after 7 and $8 \mathrm{~s}$, respectively.

As shown in Figure 4, the sample from $1400 \mathrm{~m}$ released a significant amount of smoke, which indicates non-flame ignition. The samples taken at $900 \mathrm{~m}$ and $1400 \mathrm{~m}$ which had relatively low moisture content, revealed different characteristics of ignition. Hence, there appeared to be a difference between ignition characteristics (i.e., flame or non-flame ignition) by altitude, but no consistent trend was shown. This could perhaps relate to the fact that, not only does leaf moisture content

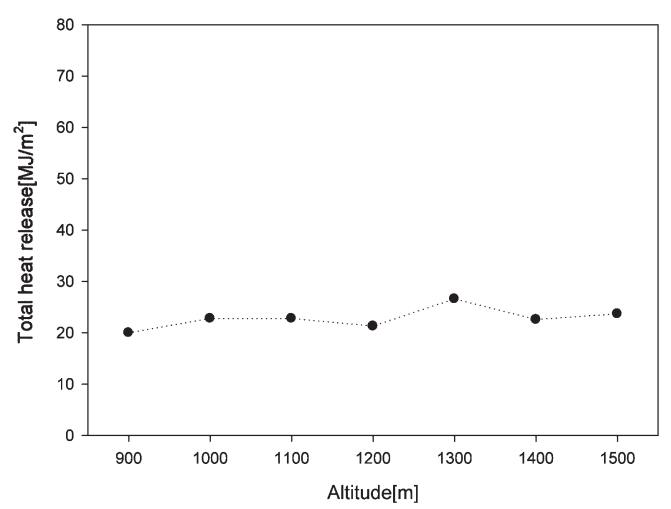

Fig. 2. Total heat release from living leaves of $P$. densiflora from various altitudes. change with altitude, but so does the nature of foliage tissue; that is, changes in cell gaps and needle components may also vary with altitude and thus affect combustion (Yim, 2007).

\section{Fire characteristics}

Total heat release was between 20 and $27 \mathrm{MJ} / \mathrm{m}^{2}$ (Fig. 2) and the mean heat release rate was between 12 and $14 \mathrm{~kW} / \mathrm{m}^{2}$ (Fig. 3). This suggests that there is little significance in the relationship between heat release and altitude. The sample taken at $1300 \mathrm{~m}$ showed a slightly higher rate of heat release than the other samples, which can be attributed to its flame rather than non-flame ignition. The sample from $1200 \mathrm{~m}$ showed the lowest heat release rate. The sample from $900 \mathrm{~m}$ experienced flame ignition, but this did not affect heat release. The outcome values are given in Table 3 .

\section{Smoke release}

\subsection{Total smoke release, maximum smoke density, and smoke temperature}

Figure 4 shows the curve for the total smoke release of samples weighing $50 \mathrm{~g}$. The sample taken at $1400 \mathrm{~m}$ released $347.23 \mathrm{~m}^{2} / \mathrm{m}^{2}$ of smoke, which is more than double the amount of smoke released by each of the other

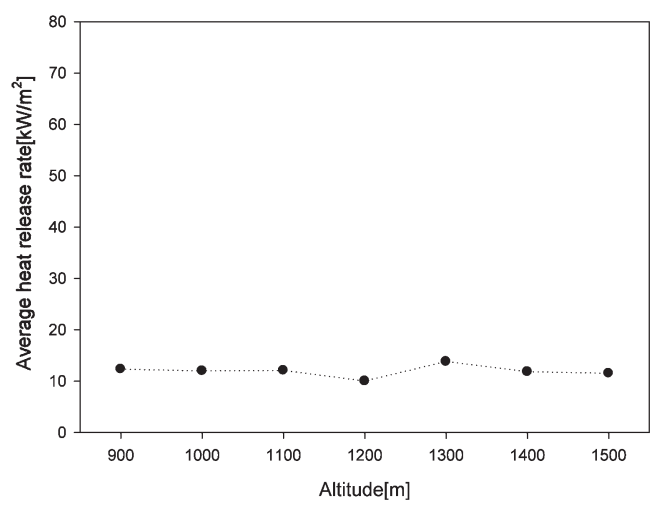

Fig. 3. Heat release rate of living leaves of $P$. densiflora from various altitudes.

Table 3. Characteristics of flame spread in living leaves of $P$. densiflora with change in altitude

\begin{tabular}{lccccccc}
\hline & \multicolumn{5}{c}{ Altitudes (m) } \\
\cline { 2 - 7 } Items & 900 & 1,000 & 1,100 & 1,200 & 1,300 & 1,400 & 1,500 \\
\hline Average HRR $\left(\mathrm{kW} / \mathrm{m}^{2}\right)$ & 12.35 & 12.01 & 12.1 & 10.03 & 13.84 & 11.87 & 11.52 \\
Total heat release $\left(\mathrm{MJ} / \mathrm{m}^{2}\right)$ & 20 & 22.8 & 22.8 & 21.3 & 26.6 & 22.6 & 23.7 \\
\hline
\end{tabular}


samples. The sample taken from $900 \mathrm{~m}$ had a maximum smoke density of 99.52 Ds at $1200 \mathrm{~s}$ (Fig. 5). The results then show no significant difference until the sample from $1400 \mathrm{~m}$, which had the maximum smoke density (143.94 Ds at $937 \mathrm{~s})$. The highest maximum smoke density, 144.96 Ds at $869 \mathrm{~s}$, was yielded by the $1500 \mathrm{~m}$ sample, which also released the most smoke over the shortest time interval.

This would suggest a positive correlation between altitude and the maximum smoke density value of the fuel. This is significant because it would imply that when

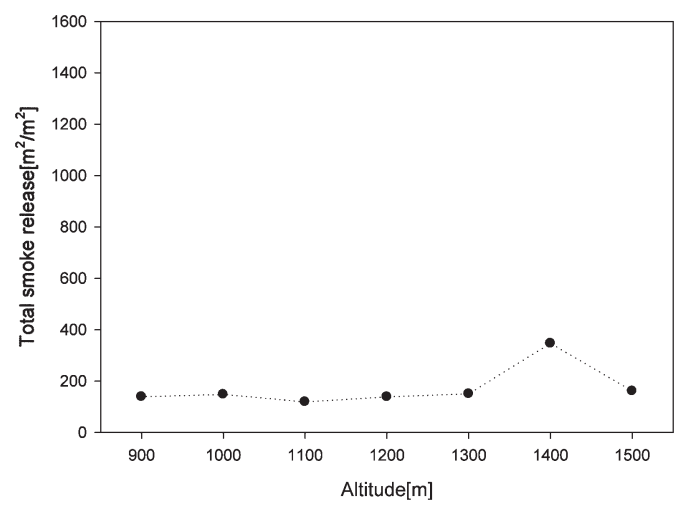

Fig. 4. Total smoke release from living leaves of $P$. densiflora from various altitudes.

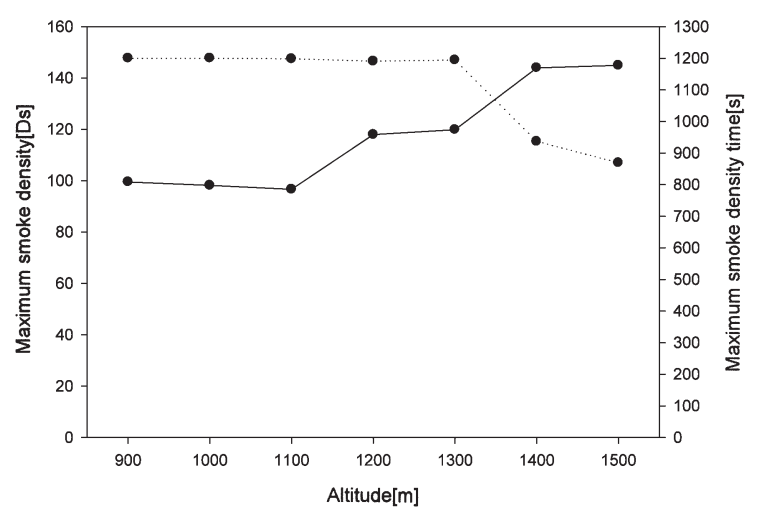

Fig. 5. Smoke density from living leaves of $P$. densiflora from various altitudes.

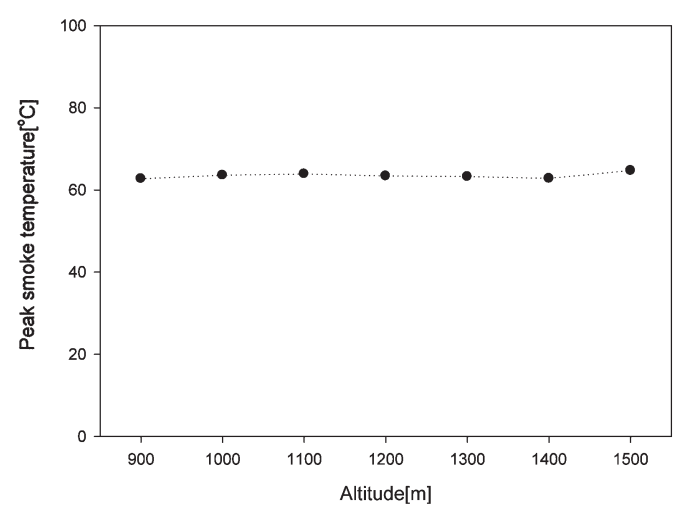

Fig. 6. Smoke temperature from living leaves of $P$. densiflora from various altitudes. forest fires erupt at higher altitudes, smoke release will reduce visibility much more than in fires at lower altitudes. Furthermore, maximum smoke density was reached in a short time, meaning that evacuation must take place rapidly after a fire breaks out. Figure 6 shows the peak smoke temperature. For smoke temperature by altitude, the range of maximum Ts was $63-65^{\circ} \mathrm{C}$, with no variation according to altitude. Table 4 presents the outcome values.

\section{2 $\mathrm{CO}$ and $\mathrm{CO}_{2}$}

The mean release density of CO rose abruptly at $1100 \mathrm{~m}$ (Fig. 7). The mean release density then decreased with higher altitude before a sudden increase at $1500 \mathrm{~m}$. Although the CO densities of the samples taken at $900 \mathrm{~m}$ and $1300 \mathrm{~m}$ were relatively low, they did exhibit flame ignition, whereas the mean release density of CO was higher for the samples taken at high altitude which had non-flame ignition. The mean release density was high in the latter type of ignition because incomplete combustion causes more CO to be released. The mean release density of $\mathrm{CO}_{2}$ showed almost the same result as that of $\mathrm{CO}$, with differences in density by altitude. The outcome values are presented in Table 5 .

The combustion products, $\mathrm{CO}$ and $\mathrm{CO}_{2}$, were produced at high temperatures, from the fuel's main component, cellulose. Patterns in the release of these combustion products are closely related to the conditions of combustion, such as the composition of the fuel, the heating temperature, and the fuel supply. Release of $\mathrm{CO}_{2}$ may also have other deleterious effects, such as contributing to the greenhouse effect. Accordingly, the density and toxicity of smoke have to be considered independently from other factors (Lee, 1993).

\section{CONCLUSIONS}

This study conducted a series of experiments on living leaves of $P$. densiflora, a species that is particularly susceptible to fire. The study aim was to compare the combustion characteristics of fuel at different altitudes. The conclusions can be summarized as follows:

1) Moisture content of the $P$. densiflora samples ranged from $148 \%$ to $177 \%$ and generally increased with altitude until $1100 \mathrm{~m}$, after which moisture content

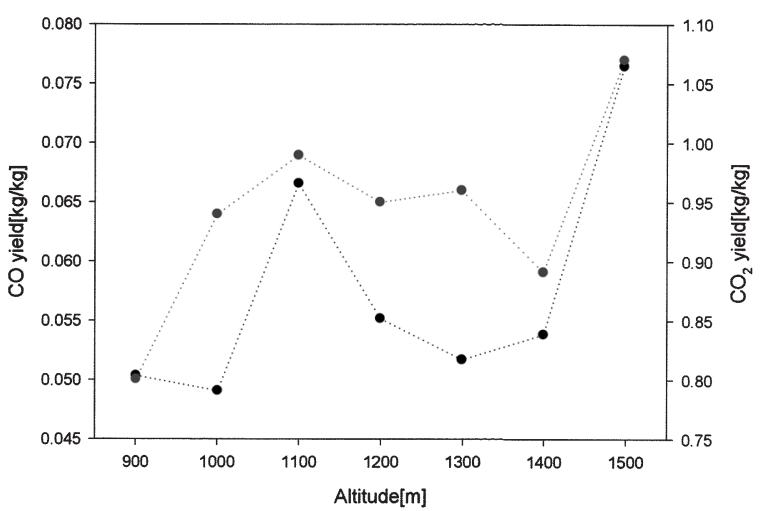

Fig. 7. $\mathrm{CO}$ and $\mathrm{CO}_{2}$ yields from living leaves of $P$. densiflora from various altitudes. 
Table 4. Characteristics of smoke release from living leaves of $P$. densiflora collected at different altitudes

\begin{tabular}{lccccccc}
\hline \multirow{2}{*}{ Items } & \multicolumn{7}{c}{ Altitudes $(\mathrm{m})$} \\
\cline { 2 - 7 } & 900 & 1,000 & 1,100 & 1,200 & 1,300 & 1,400 & 1,500 \\
\hline Total smoke release $\left(\mathrm{m}^{2} / \mathrm{m}^{2}\right)$ & 138.75 & 147.93 & 118.99 & 138.27 & 150.22 & 347.23 & 160.89 \\
Peak Smoke temp. $\left({ }^{\circ} \mathrm{C}\right)$ & 62.74 & 63.57 & 63.9 & 63.41 & 63.27 & 62.82 & 64.73 \\
Max. Smoke density (Ds) & 99.52 & 98.2 & 96.68 & 117.96 & 119.89 & 143.94 & 144.96 \\
Max. Ds time & 1200 & 1200 & 1198 & 1191 & 1194 & 937 & 869 \\
\hline
\end{tabular}

Table 5. Concentrations of combustion gases from living leaves of $P$. densiflora collected at different altitudes

\begin{tabular}{lccccccc}
\hline & \multicolumn{5}{c}{ Altitudes (m) } \\
\cline { 2 - 7 } Items & 900 & 1,000 & 1,100 & 1,200 & 1,300 & 1,400 & 1,500 \\
\hline Average CO yields & 0.0503 & 0.049 & 0.0666 & 0.0551 & 0.0516 & 0.0537 & 0.0765 \\
Average $\mathrm{CO}_{2}$ yields & 0.8 & 0.94 & 0.99 & 0.95 & 0.96 & 0.89 & 1.07 \\
\hline
\end{tabular}

decreased with elevation. However, the samples from $900 \mathrm{~m}$ and $1400 \mathrm{~m}$ both had low moisture content, thus contradicting the apparent relationship.

2) There was no significant difference between the ignition characteristics of leaves sampled at different altitudes, with non-flame temperature ranging from 305 to $310^{\circ} \mathrm{C}$. Flame ignition occurred in the samples from $900 \mathrm{~m}$ and $1300 \mathrm{~m}$, while the sample taken at $1400 \mathrm{~m}$ showed non-flame ignition with large amounts of smoke released, indicating a difference in flame and non-flame ignition by altitude.

3) Total heat release ranged from 20 to $27 \mathrm{MJ} / \mathrm{m}^{2}$ and the mean heat release rate ranged from 12 to $14 \mathrm{~kW} / \mathrm{m}^{2}$. No relationship was found between heat release and altitude. The heat release rate from the $1300 \mathrm{~m}$ sample was slightly higher than that from the other samples. This can be attributed to the occurrence of flame ignition at this altitude.

4) The sample from $1400 \mathrm{~m}$ released $347.23 \mathrm{~m}^{2} / \mathrm{m}^{2}$ smoke, which was twice as much as the release rates of the other samples. The maximum smoke density increased with sample altitude because of the large amount of smoke released at the beginning of combustion. This suggests that more smoke is released over a shorter time interval in proportion with increasing altitude.

5) The mean density of CO released during combustion increased abruptly at $1100 \mathrm{~m}$ and decreased after that point before an abrupt increase at $1500 \mathrm{~m}$. However, the samples taken at $900 \mathrm{~m}$ and $1300 \mathrm{~m}$ had low CO densities with flame ignition. The mean release density of $\mathrm{CO}_{2}$ showed almost the same pattern as for $\mathrm{CO}$, with considerable difference by altitude.

\section{ACKNOWLEDGEMENTS}

This study was carried out with the support of 'Forest Science \& Technology Projects (Project No. S210809L010130) provided by Korea Forest Service.

\section{REFERENCES}

ASTM E 662, Test method for specific optical density of smoke generated by solid materials.

Chae, H. M. and C. Y. Lee 2003 Slope and forest fuel effect on spreading of forest fire. Korean Journal of Agricultural and Forest Meteorology 5(3): 179-184 (in Korean with English abstract)

Chun, J. S., B. D. Lee, H. H. Kim and S. Y. Lee 2001 Analyzing spread rate of Samcheok forest fire broken out in 2000 using GIS. Journal of the Korea Forest Society 90(6): 781-787 (in Korean with English abstract)

Hong, Y. M. and G. S. Jung 1992 Safety engineering experiment. Donghwa Technology: 9-11 (in Korean)

ISO 5660-1 2002 Reaction to fire part 1, rate of heat release from building products (Cone Calorimeter). Generer.

ISO 5660-2 2002 Reaction-to-fire tests-Heat release, smoke production and mass loss rate-Part 2: Smoke production rate (dynamic measurement).

Jung, J. S., B. D. Lee and H. H. Kim 2002 Estimation of Pinus densiflola stand damage grades for Samcheok forest fire area using GIS and discriminate analysis. Journal of the Korea Association of Geographic Information Studies 91(3): 355-361 (in Korean with English abstract)

Kim, D. H., M. B. Lee, Y. H. Kang and S. Y. Lee 2006 The Analysis of forest fire hazard of a surface fuel through ignition test. Proceedings of the Korea Society of Hazard Mitigation Conference: 379-384 (in Korean with English abstract)

Kim, H. J., Y. K. Eum, J. J. Yi, H. S. Jung and Y. K. Choi 2004 An introduction to timber engineering. Donghwa Technology: 33-34 (in Korean)

Kim, J. W. 2005 Korean Pinus densiflola viewed through Bursaphelenchus xylophilus and forest fires of east coast area, What is the problem? Journal of Korea Ecology and field biology 28(2): 113-120 (in Korean)

Lee, B. D., S. Y, Lee and J. S. Jung 2005 The behavior characteristics of the 2005 Yangyang forest fire. Journal of the Korean Institute of Fire Science \& Engineering 19(4): 1-2 (in Korean with English abstract)

Lee. B. Y 1993 Studying on smoke and smoke detection technology. Korean Fire Protection Association. Disaster Prevention Technology 15: 28-38 (in Korean)

Lee, M. B. 2006 The characteristics of forest fire occurrence in Korea. Journal of the Korea Society of Hazard Mitigation 6(1): 31-35 (in Korean)

Lee, S. Y. 2004 Forest fire prevention system of foreign. National Institute for Disaster Prevention. Disaster Prevention Research 6(4): 25-33 (in Korean)

Shim, J. S., et al. 1994 Forest chemistry. Hyangmoonsa:137-145 (in Korean)

Yim. K. G. 2007 Forestation theory. Hangmoonsa: 47-60 (in Korean) 